\title{
Eosinophilic Granuloma Confused With Epidural Hematoma in a Trauma Case
}

\section{Travma Olgusunda Epidural Hematomla Karışan Eozinofilik Granüloma}

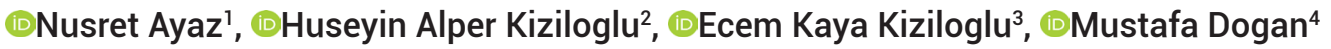 \\ 'Niğde Training and Research Hospital, Department of Forensic Medicine, Niğde, Turkey \\ ${ }^{2}$ Kayseri State Hospital, Department of Radiology, Kayseri, Turkey \\ ${ }^{3}$ Erciyes University Faculty of Medicine, Department of Dermatology, Kayseri, Turkey \\ ${ }^{4}$ Omer Halisdemir University Faculty of Medicine, Department of Forensic Medicine, Niğde, Turkey \\ Copyright@Author(s) - Available online at www.dergipark.org.tr/tr/pub/medr \\ Content of this journal is licensed under a Creative Commons Attribution-NonCommercial 4.0 International License.
}

\begin{abstract}
Emergency service physicians have forensic physician duties in addition to providing treatment and protective services. Errors in forensic report writing could affect the judicial process negatively.

A 16-year old male presented at the Emergency Department (ED) following an assault. With a diagnosis of epidural hematoma on the computed tomography taken because of head trauma, the patient was transferred to the brain surgery ward. In the forensic report written in ED, there was stated to be a danger to life. In the repeated evaluation, there was seen to be a mass in the calvarium and surgery was performed. In the histopatholgical evaluation, the diagnosis was made of Langerhans Cell Histiocytosis.

It must not be forgotten that errors or ommissions in a forensic report constitute malpractice. The necessary care and attention must be paid to forensic reports prepared in the Emergency Department.
\end{abstract}

Keywords: Langerhans cell histiocytosis; malpractice; head trauma

Öz

Acil servis hekimlerinin, koruyucu ve tedavi edici hekimlik görevlerinin yanı sıra adli hekimlik görevleri de bulunmaktadır. Adli olgulara ait tıbbi kayıtlarda yapılan hatalar adli rapor yazımı ve dolayısıyla yargılama sürecini olumsuz etkileyebilmektedir.

16 yaşında erkek olgu darp nedeniyle acil servise başvurmuştur. Kafa travması nedeni ile çekilen beyin BT'de epidural kanama tanısı ile beyin cerrahi servisine yatırılmıştır. Acil serviste yazılan adli raporda hayati tehlikesi olduğu belirtilmiştir. Tekrar yapılan değerlendirmede kalvaryumda kitle olduğu görülmüş ve ameliyat edilmiştir. Histopatolojik inceleme sonucu Langerhans Hücreli Histiyositoz tanısı konulmuştur.

Yanlış yada eksik yazılan adli raporların da malpraktis olduğu unutulmamalıdır. Acil serviste düzenlenen adli raporlarda gerekli özen ve dikkatin gösterilmesi gerekmektedir.

Anahtar Kelimeler. Langerhans hücreli histiyositoz; malpraktis; kafa travması

\section{INTRODUCTION}

Emergency service physicians have forensic physician duties in addition to providing treatment and protective services (1). As most cases presenting at the Emergency Department (ED) are forensic cases, forensic reports written in the ED are of great importance in the judicial process. According to item 280 of the Turkish Penal Code (TPC), after making the necessary interventions to forensic cases, physicians and other healthcare personnel are obliged to prepare a forensic report explaining the status of the case in appropriate language (1).

Incorrect reports are sometimes made due to workload, inexperience or incorrect test results. This can lead to problems in the forensic judicial process (2). The aim of this paper was to present the forensic and clinical discussion of a case that was reported as epidural hematoma in the ED and was then evaluated as eosinophilic granuloma. 


\section{CASE REPORT}

A 16-year old male presented at the ED after blunt head assault. In the physical examination, the patient was conscious and had complaints of headache but all other neurological findings were normal. With the initial diagnosis of trauma, a swelling on the left parietooccipital region of the head was observed. In addition, yellowish-white, sticky, squamous plaque was seen on the scalp. On the direct radiograph taken on first presentation, there was seen to be a hypodense lytic area consistent with a sharply-defined defect area in the posterior of the calvarium (Figure 1). On non-contrast brain CT, a mildly hyperdense appearance was noticed extending to the epidural area in the left parieto-occipital region, and in accordance with the radiology report, the patient was admitted to the brain surgery ward with suspected epidural hematoma.

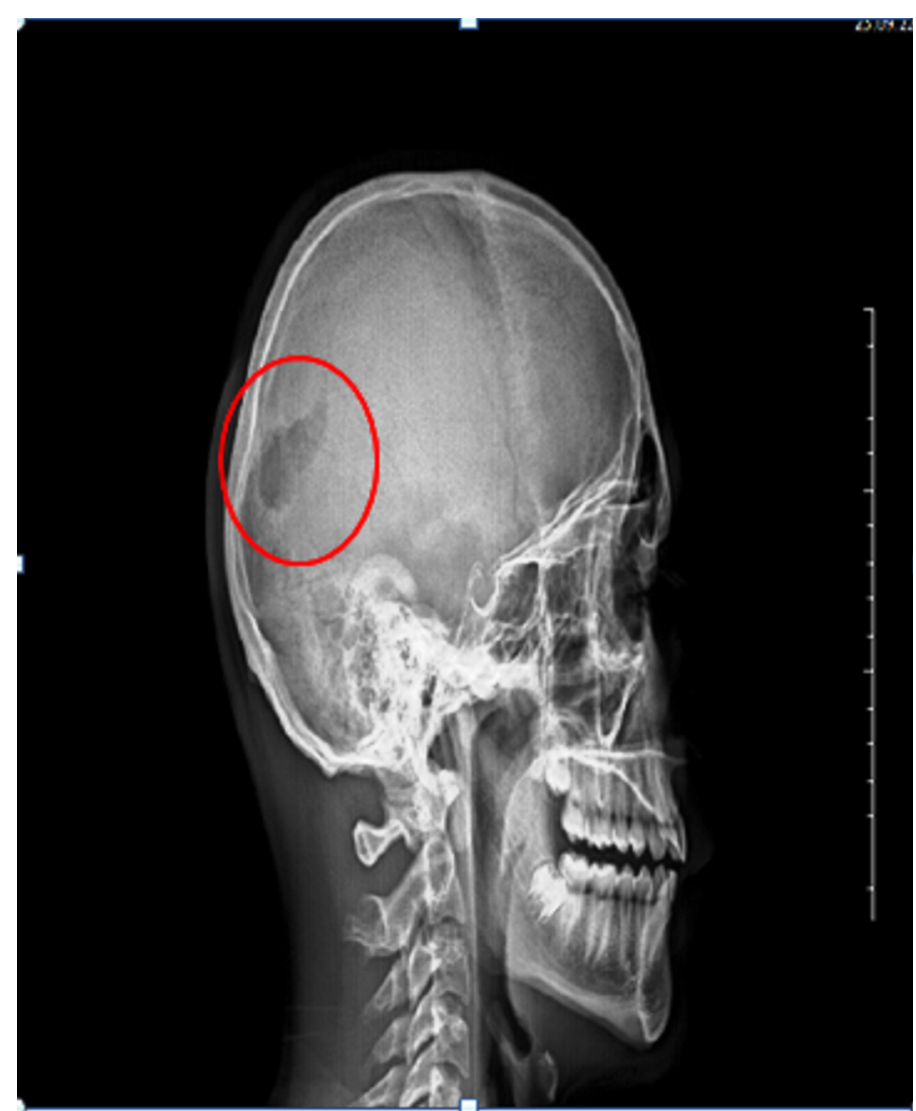

Figure 1. On the lateral head radiograph, an osteolytic hypodense lesion with sharply-defined borders was observed in the posterior of the calvarium

In the forensic report there was stated to be a danger to life because of the diagnosis of epidural hematoma and it was reported that it might not be eliminated with a simple medical intervention. Then, on contrast brain magnetic resonance imaging (MRI) taken with the initial diagnosis of mass in the calvarium, diffusion of the lesion was not restricted on the diffusion-weighted images (Figures 2A, 2B). On conventional T1-weighted MRI, there was seen to be a calvarium lesion which was mildly hypointense compared to the parenchyma, with sharply-defined borders, destroying the full layer below the scalp and extending to the epidural area (Figure 3A), on T2-weighted images, there were characteristics of hypointensity in the periphery, and the rim had hyperintense extension compared to the parenchyma (Figure 3B), and on FLAIRweighted images, there was seen to be mild signal loss compared to the T2-weighted images (Figure 3C).

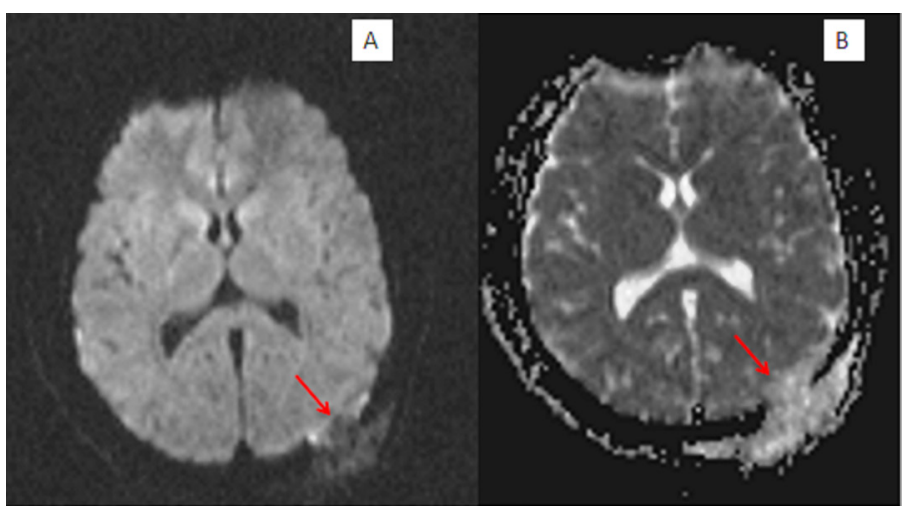

Figure 2. On the diffusion-weighted images, diffusion was not observed to be restricted in the lesion localisation

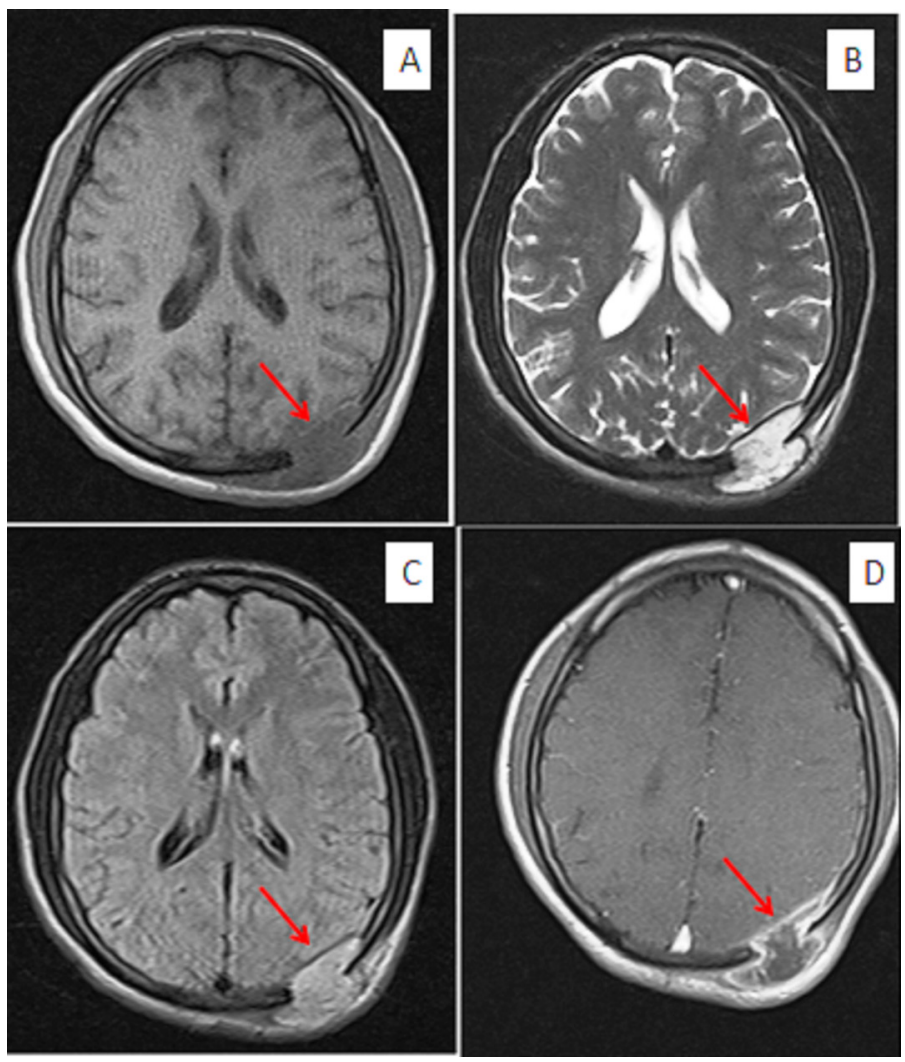

Figure 3. On evaluation of the conventional MR images; A) on T1weighted images, at the tip of the red arrow, a lesion is seen with the same signal characteristics as the brain parenchyma, which is causing a sharply-defined full layer defect in the calvarium. B) On T2-weighted images of the same lesion, the hyperintensity of the lesion is faded compared to the brain parenchyma, but there is a lower signal than from CSF, and the lesion borders can be clearly differentiated. C) On FLAIR-weighted images, a lower signal of the lesion is observed compared to the T2-weighted images. D) On post-contrast T1-weighted images, there is seen to be a lower amount of contrast from the periphery of the lesion, and there is diffuse contrast around the lesion 
On post-contrast T1-weighted images, a lesion was observed with diffuse contrast from the wall and contrast of a lower amount from the periphery (Figure 3D). After surgical excision of the lesion, Langerhans Cell histiocytosis bone involvement was reported in the histopathological evaluation. On retrospective examination of the brain CT, it was understood that the appearance in question was not an epidural hematoma and the patient had a mildly hyperdense, space-occupying lesion below the scalp showing extension to the epidural space, which was destroying the full layer of the calvarium (Figures 4A, 4B).

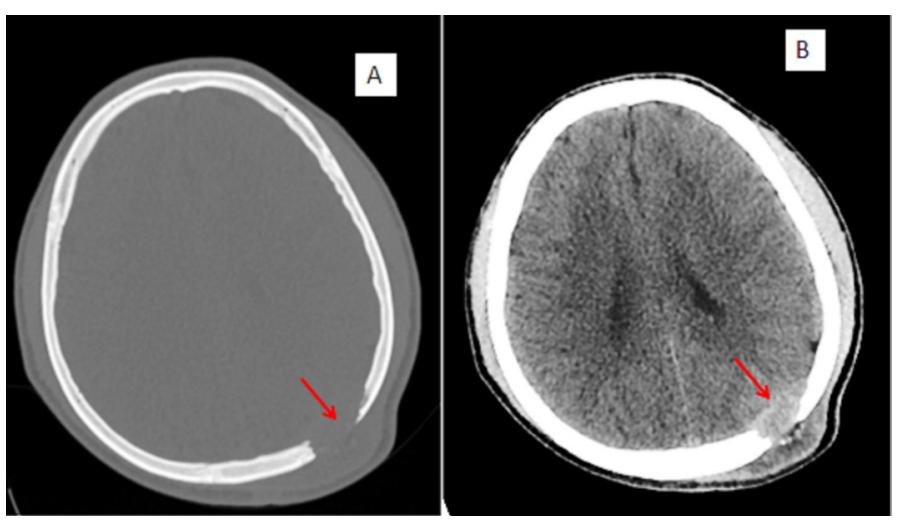

Figure 4. A) On the brain CT image, a sharply-defined full-layer defect is seen in the calvarium in the bone window and increased soft tissue thickness in the scalp. B) In the parenchyma window, a lesion is observed of mildly hyperdense soft tissue density compared to the parenchyma, extending to the scalp and epidural area together with the defect in the calvarium

\section{DISCUSSION}

Langerhans cell histiocytosis is an uncommon disease group seen in children and young adults (3). The annual incidence has been reported to be approximately $54 / 100,000$ (2). It may be seen with involvement of the lungs, liver, bones, skin, gingiva, lymph nodes, hypophysis, mucous membranes and soft tissue (4). Eosinophilic granuloma is the most frequently seen benign bone tumour subtype of Langerhans cell histiocytosis. The etiology is not fully known (4). It is seen more often in males and is often noticed in the prepubertal period (3). The current case was diagnosed incidentally at a later age as he was asymptomatic. Bone involvement is usually seen in the calvarium, mandible, vertebrae and costae. In the skull, it is most often seen in the parietal and temporal bones (5). The current case was seen to have parietal bone involvement.

In the radiological evaluation, direct radiographs, CT and $\mathrm{MRI}$ are used in determination of the lesion and provide information about the extent of the lesion (6). Thus these methods assist in diagnosis and have an effective role in planning surgery (7). On direct head radiographs, it is seen as an osteolytic, sharply-defined lesion, and on CT as a sharply-defined mass with extension to soft tissue causing destruction in the bone (7). However, it may sometimes be evaluated as epidural hematoma by inexperienced physicians. The current case had been struck on the head and presented at ED. As there was swelling in the area struck, brain CT was taken and as epidural hematoma was considered, the patient was admitted to the brain surgery ward. A forensic report was prepared by the ED physicians stating that there was danger to life and it might not be eliminated with a simple medical intervention. In forensic reports, the physician is required to report whether the injuries of the patient are life-threatening or not and whether or not the trauma will recover with a simple medical intervention (8).

There is a guideline prepared by forensic medicine specialists to assist on this subject (9). This guideline describes in detail the effect of injury on the body. Lifethreatening situations like epidıral hematoma and other situations that should be considered while writing in the forensic report are described in the guideline. Physicians should use this guideline while writing forensic reports.

Errors or omissions in the report will have negative effects on the forensic judicial process. There could even be an investigation into neglect of duty (8). As a result of such mistakes that may occur while performing a judicial duty, according to item 257 of the Turkish Penal Code, trials for "misconduct" may be in question (10). There is also a possibility of defendants claiming to have remained longer in prison or to have suffered greater financial or emotional losses because of errors in the report (11). According to Turkish Civil Procedure Code item 285 The state recovers the responsible expert (physician) for the compensation it has paid because of written wrong forensic report (12).

\section{CONCLUSION}

In conclusion, a physician will be held legally responsible for all kinds of error or omission made when preparing a forensic report just as in other malpractice cases, which could result in punishments and compensation cases. In addition to following up in-service professional training on this subject, an increase in the quality of training should be provided. Also writing reports after the necessary examinations and consultation procedures in forensic cases will decrease making mistakes for physicians.

Financial disclosures: All authors report no financial interests or potential conflicts of interest.

Conflict of Interest: The authors declare that they have no competing interest.

Informed Consent: Informed consent was taken from the patient.

\section{REFERENCES}

1. Beyaztaş FY. Adli rapor konusunda hekim sorumluluğu. Anadolu Psikiyatri Dergisi 2000;1:231-4.

2. Yavuz MF, Yavuz MS. Adli rapor standardizasyonu ve adli raporlarda görülen eksiklikler. Türkiye Klinikleri J Surg Med Sci 2006;2:28-33.

3. Majumder A, Wick CC, Collins R, et al. Pediatric Langerhans cell histiocytosis of the lateral skull base. Int J Pediatr 
Otorhinolaryngol 2017;99:135-40.

4. El Demellawy D, Young JL, de Nanassy J, Chernetsova E,Nasr A. Langerhans cell histiocytosis: a comprehensive review. Pathology 2015;47:294-301.

5. Hegemann MV, Schreml S. Multisystemic Langerhans cell histiocytosis in an adult. JAAD Case Rep 2017;3:162-4.

6. Wang $Y$, Camelo-Piragua S, Abdullah A, et al. Neuroimaging features of CNS histiocytosis syndromes. Clin Imaging 2019;60:131-40.

7. Zaveri J, La Q, Yarmish G, et al. More than just Langerhans cell histiocytosis: a radiologic review of histiocytic disorders. Radiographics 2014;34:2008-24.

8. Serinken $M$, Türkçüer I, Acar $K$, et al. Acil servis hekimleri tarafından düzenlenen adli raporların eksiklik ve yanlışlıklar yönünden değerlendirilmesi. Ulus Travma Acil Cerrahi Derg. 2011;17:23-8.

9. Balcı Y, Çolak B, Gürpınar K, Anolay NN. Türk Ceza Kanunu'nda Tanımlanan Yaralama Suçlarının Adli Tıp Açısından Değerlendirilmesi Rehberi, 2019. https://www.atk.gov.tr/ tckyaralama24-06-19.pdf Erişim Tarihi: 15.02.2021.

10. 5237 sayılı Türk Ceza Kanunu. Erişim adresi: http: //www. tbmm.gov.tr/ kanunlar /k5237. Erişim tarihi: 15.02.2021.

11. Turla A, Aydın B, Sataloğlu N. Acil serviste düzenlenen adli raporlardaki hata ve eksiklikler. Ulus Travma Acil Cerrahi Derg. 2009;15:180-4.

12. 6100 sayılı Hukuk Muhakemeleri Kanunu. https:// www. resmigazete.gov.tr/20110204-2. access date: 15.02.2021. 